\title{
Patterns and Trends in Adolescents' Contraceptive Use and Discontinuation in Developing Countries and Comparisons With Adult Women
}

CONTEXT: The reproductive choices made by young women and men have an enormous impact on their health, schooling, employment prospects and overall transition to adulthood. As the largest cohort of young people in history enter their childbearing years, their reproductive behavior will determine the growth and size of the world's population for decades to come.

METHODS: Demographic and Health Survey data from more than 40 countries were used to examine the proportions of 15-19-year-old women who are currently married or are unmarried but sexually active; their rates of contraceptive adoption, current use, discontinuation, method switching and contraceptive failure; trends in these indicators; and comparisons with older women.

RESULTS: In many countries, the proportion of adolescent women using contraceptives increased substantially over the last two decades; prevalence among adolescents increased faster than among older women. Greater proportions of adolescents than of older women discontinued using a contraceptive method within a year or experienced contraceptive failure.

CONCLUSIONS: Adolescent contraceptive use is growing, and compared with adult use, is characterized by shorter periods of consistent use with more contraceptive failure and more stopping for other reasons. Use through the reproductive years is likely to grow, fueled further by growth in the numbers of young people. An expanded demand for contraceptive supplies, services and information can be expected to challenge the preparedness, capacity and resources of existing family planning programs and providers.

International Perspectives on Sexual and Reproductive Health, 2009, 35(2):63-71

The reproductive choices made by young women and men have an enormous impact on their health, schooling and employment prospects, as well as their overall transition to adulthood. ${ }^{1,2}$ In particular, school and work opportunities significantly influence young women's and men's marriage timing, quality of parenthood and ability to contribute to their families and society. ${ }^{1,3,4}$ Young women's reproductive choices are especially important, as early childbearing can impair their health and limit their prospects for productive participation in society.

The literature suggests that, in general, sexually active unmarried adolescents are not seeking to become pregnant, and married adolescents wish not to become pregnant at a young age or, if they have already had a child, wish to delay a second pregnancy. ${ }^{5}$ In nine national surveys conducted in South and Southeast Asian countries between 1996 and 1999, contraceptive prevalence among married female adolescents ranged from $6 \%$ in Nepal and Pakistan to $43-44 \%$ in Thailand and Indonesia. ${ }^{6}$

According to a study of nearly 34,000 15-year-old male and female students in 23 European countries and Canada, $14-38 \%$ were sexually experienced, ${ }^{7} 82 \%$ of sexually active students reported using condoms or pills at last intercourse. Another study of 18 Demographic and Health Surveys conducted in Africa between 1993-2001 found that two out of five unmarried females aged 15-24 were sexually active ${ }^{8}$ unlike the results from Europe and Cana$\mathrm{da}$, however, the median proportion reporting any contraceptive use by 2001 was just 37\%.

Although levels of sexual activity and contraceptive use are both substantial among adolescents in the developing world, the upward shift in the former tends to be faster than in the latter. 9,10 According to a study of 27 SubSaharan countries, there was no pervasive shift toward early (before age 18) sexual initiation between 1994 and 2004, although the prevalence of premarital sex before age 18 increased significantly in 19 countries. ${ }^{11}$ Condom use for pregnancy prevention rose significantly during the period, from 5\% to 19\%. Similar trends in condom use are found in the reproductive and contraceptive histories of single women aged 15-24 in eight Latin American countries, ${ }^{9}$ where use of condoms increased faster than reliance on any other method used by this group.

Contraceptive continuation over sustained periods of time is not assured, and discontinuation occurs for reasons of failure, method features, such as side effects or convenience of use, or change in need. Some women stop using altogether or immediately switch to another method, whereas others experience a gap in pregnancy protection of a month or more. Discontinuation is a par-

\author{
By Ann K.Blanc, \\ Amy O.Tsui, \\ Trevor N.Croft and \\ Jamie L.Trevitt
}

Ann K. Blanc is director, Maternal Health Task Force, EngenderHealth, New York. Amy O. Tsui is director, Bill and Melinda Gates Institute for Population and Reproductive Health, and Jamie L.

Trevitt is a doctoral candidate, both with Johns Hopkins Bloomberg School of Public Health, Baltimore, MD, USA. Trevor N. Croft is vice president, Blancroft Research International, Columbia, MD. 
ticularly important issue for adolescents and young women because they tend to have more limited access than older individuals to family planning, as well as more unpredictable and irregular sexual activity, and are probably less knowledgeable about how to use contraceptive methods effectively. ${ }^{10}$ According to a study of six developing countries, women younger than 25 were more likely than others to stop using their contraceptive method after 24 months. $^{12}$

Unplanned pregnancies among adolescents happen despite the best of contraceptive intentions, and the effectiveness of adolescent pregnancy prevention programs remains below desired levels. ${ }^{13-15}$ Adolescents' success in avoiding pregnancy often depends on having access to contraceptive information, methods and services. According to estimates from 2000, close to $25 \%$-or 11 millionmarried women aged 15-19 in the developing world and former Soviet Union have an unmet need for contraception (i.e., have a desire to avoid or delay pregnancy, but are not using any contraceptive method); this estimate does not include unmet need among never-married, sexually active women. ${ }^{16}$

In this study, we provide an overview of country-level change in sexual activity, contraceptive use and contraceptive discontinuation among adolescent females in the developing world. In addition, we compare annual rates of change in contraceptive use and rates of discontinuation across age-groups. Specifically, we address three questions. What proportions of female adolescents are sexually active and thus exposed to the risk of pregnancy, and how have these levels changed over time? What are the levels of and trends in adolescent females' contraceptive use? And what proportions of adolescent contraceptive users stop using, switch methods or experience a contraceptive failure, and how do these proportions compare with those for older users?

\section{DATA AND METHODS}

We used nationally representative Demographic and Health Survey (DHS) data from more than 40 developing countries in Africa, Asia and Latin America. The exact number of countries included in each analysis varies by the availability of data for each country. The surveys were conducted between 1986 and 2006; 45 countries had two or more surveys during that time, and we used these data to examine trends and rates of change over time. For countries with more than two surveys during the period, we selected the earliest and latest. The interval between the in-

*We defined "sexually active" as having had sexual intercourse in the four weeks preceding the survey.

+See reference 17 for a discussion of the quality of the contraceptive histories in DHS calendar data.

‡This methodology allowed us to utilize data from respondents up to age 24 at the time of the survey who were asked to report on behavior over the last five years, which would cover some or all of the years between ages 15 and 19, depending on the current age of the respondent.

$\S$ For comprehensive documentation and discussion of this trend, see reference 1 , chapter 7 . dividual country surveys varies; the average interval is almost 11 years.

To assess youths' exposure to the risk of pregnancy and their potential need for contraception, we examined the proportion of adolescents who reported being married, as well as the proportion who said they were unmarried but sexually active, ${ }^{*}$ for countries with two survey rounds in the 1986-2006 period.

For 21 countries, detailed contraceptive histories were collected. Female respondents were asked to report whether they had used a contraceptive method during each month of the five or three years prior to the survey (depending on survey), and if so, which method they had used. For months in which a woman reported discontinuing the use of a method, she was asked the main reason. ${ }^{\dagger}$ Using data from the contraceptive histories, we examined the rate at which adolescent females adopted contraceptives. We included the experience of women who were 15-19 at any time during the five years prior to the survey to calculate the cumulative proportion who had ever used a contraceptive method by single years of age. ${ }^{\dagger}$ In addition, we calculated life table rates of contraceptive discontinuation. We compared the pattern for 15-19-yearolds to that for women aged 20-49, to highlight the distinctive characteristics of adolescent contraceptive dynamics.

Using DHS contraceptive histories, we constructed multiple decrement life tables that categorize the reasons for contraceptive method discontinuation into four groups: method failure, method switching, abandoned (in need) and abandoned (not in need). ${ }^{17}$ A contraceptive failure occurs when a woman becomes pregnant while she is using a method. The category abandoned (in need) includes women who reported discontinuing method use because their husband disapproved, they wanted a more effective method or their method was inconvenient to use; women who discontinued because of side effects, health concerns, access or availability problems or other reasons; and those who responded "don't know." The category abandoned (not in need) includes women who stopped using because they wanted to become pregnant or because of infrequent sex, menopause or infecundity, or marital dissolution. Women who reported being sterilized were excluded from the calculations.

\section{RESULTS}

\section{Exposure to the Risk of Pregnancy}

The proportion of females aged 15-19 who reported in the most recent survey being married varied dramatically across countries-from more than $40 \%$ in Bangladesh, Chad, Mali and Niger to fewer than 10\% in Armenia, Jordan, Kazakhstan, Namibia, the Philippines, Rwanda and Vietnam (Table 1). In most of the African and Asian countries, the proportion of married adolescents declined over time, regardless of the prevalence of teenage marriage (see Web Appendix Figure 1 at http://www.guttmacher.org/ pubs/ipsrh/appendix/3506309.pdf).\& Particularly large 


\begin{tabular}{|c|c|c|c|c|c|c|c|}
\hline $\begin{array}{l}\text { Country and } \\
\text { survey year }\end{array}$ & No. & Married & $\begin{array}{l}\text { Unmarried/ } \\
\text { sexually active }\end{array}$ & $\begin{array}{l}\text { Country and } \\
\text { survey year }\end{array}$ & No. & Married & $\begin{array}{l}\text { Unmarried/ } \\
\text { sexually active }\end{array}$ \\
\hline Armenia, 2000 & 1,160 & 8.5 & 0.0 & Kazakhstan, 1999 & 791 & 8.0 & 5.0 \\
\hline Armenia,2005 & 1,123 & 6.9 & 0.0 & Kenya, 1989 & 1,497 & 18.5 & 6.4 \\
\hline Bangladesh, 1994 & 2,912 & 42.0 & $\mathrm{u}$ & Kenya,2003 & 1,856 & 17.9 & 3.6 \\
\hline Bangladesh,2004 & 3,533 & 43.5 & $\mathrm{u}$ & Madagascar, 1992 & 1,420 & 21.4 & 15.6 \\
\hline Benin, 1996 & 1,075 & 28.6 & 9.0 & Madagascar, 2004 & 1,528 & 27.2 & 9.7 \\
\hline Benin, 2006 & 3,067 & 21.7 & 8.9 & Malawi, 1992 & 1,082 & 35.8 & $\mathrm{u}$ \\
\hline Bolivia, 1989 & 1,682 & 12.5 & 1.1 & Malawi,2004 & 2,392 & 32.9 & 3.6 \\
\hline Bolivia, 2003 & 3,874 & 11.0 & 3.3 & Mali, 1987 & 523 & 71.5 & 0.9 \\
\hline Brazil, 1986 & 1,305 & 13.2 & 3.1 & Mali, 2001 & 2,565 & 45.9 & 6.5 \\
\hline Brazil, 1996 & 2,464 & 13.8 & 8.8 & Morocco, 1987 & 2,406 & 11.5 & $\mathrm{u}$ \\
\hline Burkina, 1993 & 1,373 & 44.2 & 4.3 & Morocco, 2003 & 3,295 & 10.5 & $\mathrm{u}$ \\
\hline Burkina, 2003 & 2,776 & 31.6 & 5.6 & Mozambique, 1997 & 1,836 & 45.0 & 11.0 \\
\hline Cambodia, 2000 & 3,618 & 12.1 & 0.1 & Mozambique, 2003 & 2,454 & 38.2 & 16.4 \\
\hline Cambodia,2004 & 3,602 & 10.1 & 0.1 & Namibia, 1992 & 1,259 & 6.9 & 16.4 \\
\hline Cameroon, 1991 & 919 & 41.1 & 11.3 & Namibia, 2000 & 1,499 & 5.0 & 11.8 \\
\hline Cameroon, 2004 & 2,685 & 30.9 & 7.0 & Nepal, 1996 & 2,229 & 43.3 & $\mathrm{u}$ \\
\hline Chad, 1997 & 1,716 & 46.7 & 3.7 & Nepal,2006 & 2,437 & 32.2 & 0.1 \\
\hline Chad, 2004 & 1,361 & 42.0 & 2.1 & Nicaragua, 1998 & 3,307 & 25.6 & 1.2 \\
\hline Colombia, 1986 & 1,208 & 12.3 & 2.3 & Nicaragua,2001 & 3,141 & 22.3 & 2.4 \\
\hline Colombia, 2005 & 7,589 & 12.3 & 10.9 & Niger, 1992 & 1,379 & 56.5 & 0.6 \\
\hline Cote D'Ivoire, 1994 & 1,961 & 26.4 & 19.4 & Niger,2006 & 1,718 & 59.0 & 0.2 \\
\hline Cote D'Ivoire, 1998 & 775 & 23.9 & 18.3 & Nigeria, 1990 & 1,612 & 37.0 & 10.2 \\
\hline Dom.Rep., 1986 & 1,960 & 16.7 & 0.0 & Nigeria,2003 & 1,716 & 31.7 & 6.8 \\
\hline Dom.Rep., 2002 & 4,550 & 22.4 & 4.1 & Peru, 1986 & 1,097 & 11.7 & 0.0 \\
\hline Egypt, 1992 & 3,037 & 13.7 & $\mathrm{u}$ & Peru, 2004 & 2,283 & 10.0 & 4.3 \\
\hline Egypt,2005 & 6,446 & 12.3 & $\mathrm{u}$ & Philippines, 1993 & 3,158 & 7.4 & 0.1 \\
\hline Eritrea, 1995 & 1,129 & 32.5 & 0.0 & Philippines, 2003 & 2,648 & 9.0 & 0.2 \\
\hline Eritrea, 2002 & 2,001 & 29.0 & 0.4 & Rwanda, 1992 & 1,464 & 8.4 & 0.9 \\
\hline Ethiopia,2000 & 3,710 & 23.2 & 1.1 & Rwanda, 2005 & 2,585 & 2.5 & 0.8 \\
\hline Ethiopia, 2005 & 3,266 & 21.8 & 0.4 & Senegal, 1986 & 975 & 41.9 & 0.0 \\
\hline Ghana, 1988 & 849 & 20.5 & 10.2 & Senegal,2005 & 3,556 & 28.5 & $\mathrm{u}$ \\
\hline Ghana,2003 & 1,148 & 12.0 & 8.0 & Tanzania, 1992 & 2,183 & 25.6 & 11.8 \\
\hline Guatemala, 1987 & 1,182 & 23.6 & 0.4 & Tanzania, 2004 & 2,245 & 26.3 & 7.4 \\
\hline Guatemala, 1999 & 1,332 & 23.8 & 0.2 & Togo, 1988 & 724 & 26.5 & 14.5 \\
\hline Guinea, 1999 & 1,321 & 43.9 & 6.4 & Togo, 1998 & 1,787 & 19.1 & 16.5 \\
\hline Guinea,2005 & 1,648 & 35.6 & 9.0 & Turkey, 1993 & 2,460 & 13.4 & $\mathrm{u}$ \\
\hline Haiti, 1994 & 1,290 & 14.9 & 5.4 & Turkey, 2003 & 2,003 & 11.9 & $\mathrm{u}$ \\
\hline Haiti, 2005 & 2,701 & 16.6 & 5.6 & Uganda, 1988 & 1,157 & 36.5 & 7.5 \\
\hline India, 1993 & 23,147 & 38.4 & $\mathrm{u}$ & Uganda,2006 & 1,936 & 19.6 & 4.1 \\
\hline India,2006 & 24,811 & 27.1 & 0.1 & Vietnam, 1997 & 1,661 & 7.7 & $\mathrm{u}$ \\
\hline Indonesia, 1987 & 3,638 & 16.5 & $\mathrm{u}$ & Vietnam, 2002 & 1,630 & 4.1 & $\mathrm{u}$ \\
\hline Indonesia, 2002 & 6,531 & 14.0 & $\mathrm{u}$ & Zambia, 1992 & 1,984 & 26.5 & 12.1 \\
\hline Jordan, 1990 & 3,394 & 10.4 & $\mathrm{u}$ & Zambia, 2002 & 1,812 & 24.2 & 7.1 \\
\hline Jordan, 2002 & 2,563 & 6.0 & $\mathrm{u}$ & Zimbabwe, 1988 & 1,021 & 17.6 & 4.5 \\
\hline Kazakhstan, 1995 & 669 & 12.0 & 4.1 & Zimbabwe,2005 & 2,152 & 20.8 & 1.6 \\
\hline
\end{tabular}

and consistent declines of 10 percentage points or more occurred over the course of about a decade in Burkina Faso, Cameroon, India, Mali, Nepal, Senegal and Uganda. Some evidence suggests that the trend toward increasing age at marriage is linked to urbanization and the expansion of education among young women, factors that are also linked to contraceptive use. ${ }^{2,4}$

The proportion of women aged 15-19 who reported being unmarried and sexually active varied widely by country. At the upper end of the range, $10-18 \%$ of unmarried adolescent females in Colombia, Cote D'Ivoire, Mozambique, Namibia and Togo reported being sexually active at the most recent survey. In most countries, the proportion of 15-19-year-old women who reported being married exceeded the proportion who were unmarried but sexually active; Namibia is a notable exception. In general, the vast majority of adolescent women at risk of pregnancy were married.
Among the roughly 30 countries for which data from two surveys were available, no consistent trend across time was evident (Figure 1, page 66). Some countries had large (greater than five percentage points) increases from the earlier to later survey in the proportion who were sexually active (e.g., Brazil, Colombia and Mali), but others had noticeable (greater than two percentage points) declines (e.g., Kenya, Tanzania, Uganda and Zambia). It is difficult to generalize about trends, especially given questions about the quality and consistency of the data on sexual activity, although the direction in Sub-Saharan Africa is mostly downward. ${ }^{11}$

\section{Adoption of Contraception}

Among the 25 countries with appropriate data from the most recent survey, roughly $25 \%$ of all young women, on average, had used contraceptives by age 19; ever-use by age 19 was as high as $51-61 \%$ in Bangladesh, Brazil and 
FIGURE 1. Trends in percentage of unmarried sexually active females aged 15-19 in countries with two rounds of Demographic and Health Surveys, by earliest and most recent survey, 1986-2006

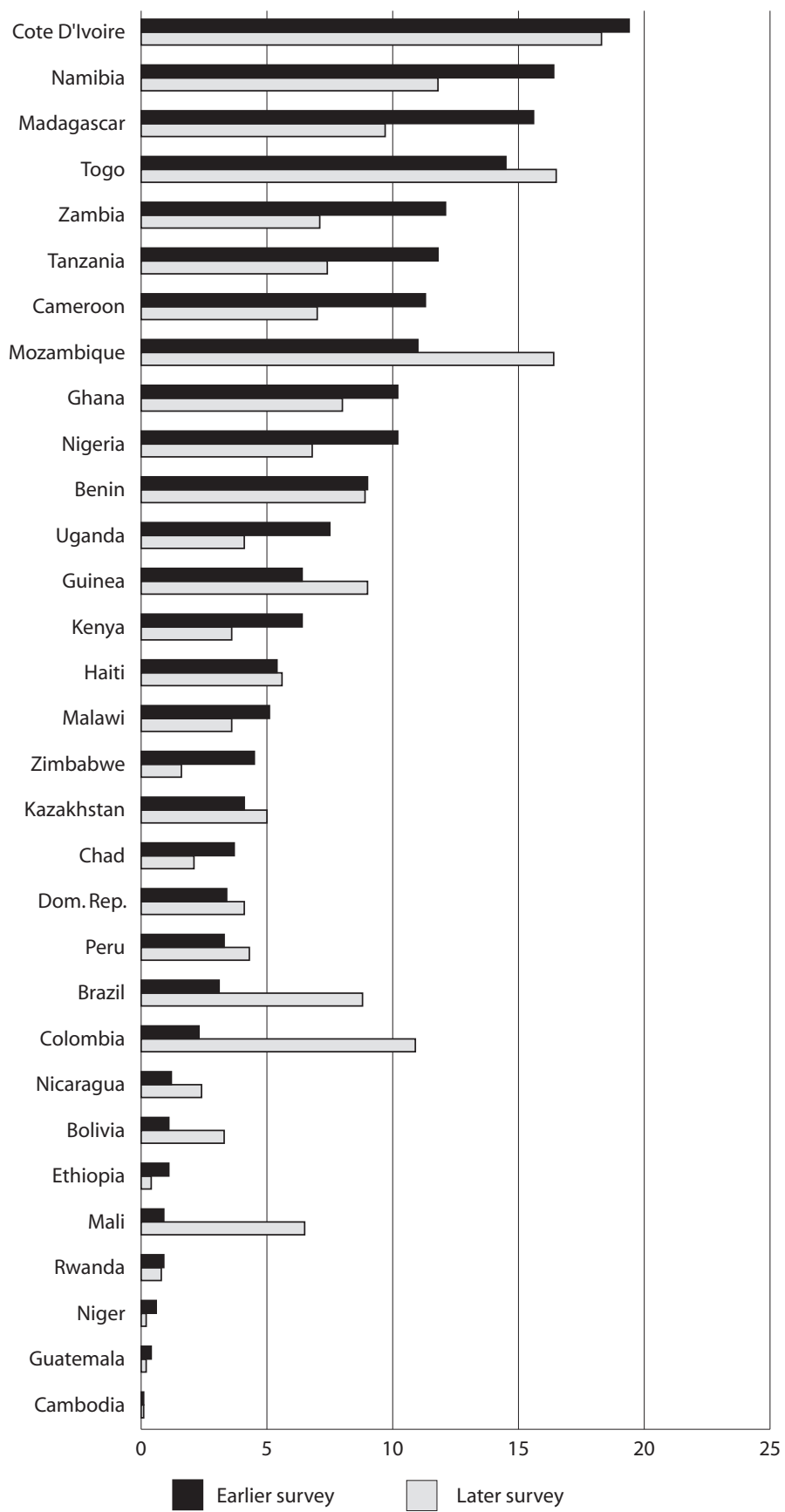

Colombia (not shown). Among the 16 countries with contraceptive history data for at least two surveys, 12 experienced increases in the proportion of adolescent females using contraceptives by age 19 of $2-17 \%$ annually during the period between the two surveys; results for four countries from different regions (Bangladesh, Colombia, Egypt and Zimbabwe) are shown in Web Appendix Figure 2 (http://www.guttmacher.org/pubs/ipsrh/appendix/ 3506309.pdf). The proportion of women who had ever used a method by age 19 rose from $23 \%$ to $60 \%$ in Colom- bia between 1990 and 2005; in Bangladesh, that proportion rose from 39\% to 61\% between 1994 and 2004. The two countries had similar patterns of contraceptive adoption in spite of different levels of exposure to pregnancy: Nearly $44 \%$ of adolescent women in Bangladesh were married, * whereas only $23 \%$ of same-aged Colombians were either married or unmarried but sexually active. In 2005, only $10 \%$ of Egyptian 19-year-olds had ever used contraceptives; this proportion was only three percentage points higher than in 1992. In Zimbabwe, about a third of young women had used contraceptives by age 19 , and the proportion changed little between 1994 and 2005.

\section{Levels and Trends in Current Use of Contraceptives}

In the most recent survey, $42-68 \%$ of married and unmarried but sexually active adolescent females in all the Latin American countries (except Guatemala and Haiti) and in Bangladesh, Indonesia, Kazakhstan and Turkey reported currently using contraceptives (Table 2). Among the African countries, there were nine in which contraceptive prevalence was 20-35\%, but only one-Namibiain which it reached at least $40 \% .^{\dagger}$ The lowest levels of contraceptive use occurred in five countries of the African Sahel-Chad, Eritrea, Mali, Niger and Senegal. In Nigeria, the most populous country in the Sahel-as well as in Africa as a whole-only $12 \%$ of adolescent females used contraceptives, although there were wide regional variations in prevalence (not shown).

Overall, current use of contraceptives was higher among sexually active, unmarried adolescents than among married youth (for example, 38\% vs. 60\% in Kazakhstan, and 4\% vs. 45\% in Nigeria). Presumably, this pattern reflects unmarried youth's stronger desire to avoid pregnancy. The difference in prevalence between the two groups was very large in some countries, especially those in West Africa, where it was not unusual for the level of use among unmarried adolescents to be four or more times greater than that among married youth (for example, 54\% vs. $8 \%$ in Benin). The differential tended to be greatest in countries in which married women had low levels of contraceptive use.

Along with wide disparities across countries in the levels of contraceptive use, there was considerable variation in the predominant contraceptive method used by 15-19year-old females (not shown). In 28 countries, the most commonly used method according to the most recent survey was either the pill or the injectable ( 14 each); in 12, traditional methods, including periodic abstinence; in eight countries, the condom; and in 10 countries, the IUD or withdrawal (five each). In general, the trend between surveys was from traditional methods toward more effective modern methods. In the Philippines, however, the main

*Data of the proportion of women in Bangladesh who are unmarried but sexually active is unavailable.

†Although not shown in Table 2 (because they have only one survey each), four countries in Africa have reached prevalence of $40 \%$ or moreCongo, Gabon, Namibia and South Africa. 

TABLE 2. Percentage of women aged 15-19 using contraceptives at interview, by marital and sexual status, according to
country and survey year

\begin{tabular}{llll}
$\begin{array}{l}\text { Countryand } \\
\text { survey year }\end{array}$ & Married & $\begin{array}{l}\text { Unmarried/ } \\
\text { sexually active }\end{array}$ & $\begin{array}{l}\text { Married and } \\
\text { unmarried/ } \\
\text { sexually active }\end{array}$ \\
\hline Armenia, 2000 & 25.5 & $\mathrm{u}$ & $25.5^{*}$
\end{tabular}

$\begin{array}{lrcl}\text { Armenia,2000 } & 25.5 & \mathrm{u} & 25.5^{*} \\ \text { Armenia,2005 } & 16.5 & \mathrm{u} & 16.5^{*} \\ \text { Bangladesh, 1994 } & 24.7 & \mathrm{u} & 24.7^{*} \\ \text { Bangladesh,2004 } & 42.2 & \mathrm{u} & 42.2^{*} \\ \text { Benin, 1996 } & 9.4 & 47.2 & 18.4\end{array}$

Benin, 1996

Bolivia, 1989

Bolivia, 2003

Brazil, 1986

Brazil, 1996

Burkina, 1993

Burkina, 2003

Cambodia, 2000

Cambodia, 2004

Cameroon, 1991

Cameroon, 2004

Chad, 1997

Chad, 2004

Colombia, 1986

Colombia, 2005

Cote D'Ivoire, 1994

Cote D'Ivoire, 1998

Dom. Rep., 1986

Dom. Rep., 2002

Egypt, 1992

Egypt, 2005

Eritrea, 1995

Eritrea, 2002

Ethiopia, 2000

Ethiopia, 2005

Ghana, 1988

Ghana, 2003

Guatemala, 1987

Guatemala, 1999

Guinea, 1999

Guinea, 2005

Haiti, 1994

Haiti, 2005

India, 1993

India, 2006

Indonesia, 1987

Indonesia, 2002

Jordan, 1990

Jordan, 2002

Kazakhstan, 1995

$\begin{array}{lll}7.9 & 53.9 & 21.2\end{array}$

$\begin{array}{ccc}7.9 & 53.9 & 21.2 \\ 16.0 & \mathrm{u} & 15.1^{*}\end{array}$

$\begin{array}{lll}45.6 & 49.7 & 46.5\end{array}$

$\begin{array}{lll}47.8 & 32.6 & 44.9\end{array}$

$\begin{array}{lll}54.1 & 66.0 & 58.7\end{array}$

$\begin{array}{lll}13.9 & 31.0 & 15.4\end{array}$

$\begin{array}{lll}6.8 & 50.4 & 13.3\end{array}$

$\begin{array}{rrr}8.9 & u & 9.3^{*} \\ 20.8 & u & 20.6^{*}\end{array}$

$\begin{array}{lll}20.8 & u & 20.6 \\ 18.4 & 64.6 & 28.3\end{array}$

$\begin{array}{lll}23.6 & 73.9 & 33.0\end{array}$

$\begin{array}{lll}3.1 & 14.2 & 3.9\end{array}$

$\begin{array}{lll}2.2 & 4.8 & 2.3\end{array}$

$\begin{array}{lll}28.9 & 44.9 & 31.5\end{array}$

$\begin{array}{lll}57.2 & 79.5 & 67.6\end{array}$

$\begin{array}{lll}8.7 & 47.0 & 24.9\end{array}$

$\begin{array}{lll}10.7 & 54.1 & 29.5\end{array}$

$24.6 \mathrm{u} \quad 24.6^{*}$

$\begin{array}{lll}41.5 & 41.4 & 41.5\end{array}$

$13.3 \mathrm{u} \quad 13.3^{*}$

$\begin{array}{rl}26.3 & u \\ 3.3 & 26.3^{*}\end{array}$

$\begin{array}{lll}2.4 & \mathrm{u} & 3.1^{*}\end{array}$

$\begin{array}{lll}3.9 & 45.7 & 5.9\end{array}$

8.9 u $9.7^{*}$

$\begin{array}{lll}4.6 & 26.4 & 11.9\end{array}$

$\begin{array}{lll}8.4 & 46.2 & 23.5\end{array}$

$\begin{array}{rrr}5.4 & u & 5.6^{*} \\ 14.6 & u & 14.8^{*}\end{array}$

$\begin{array}{rrr}14.6 & \mathrm{u} & 14.8^{*} \\ 3.4 & 42.4 & 8.4\end{array}$

$\begin{array}{lll}8.8 & 42.6 & 15.6\end{array}$

$\begin{array}{lll}10.7 & 23.2 & 14.1\end{array}$

$\begin{array}{lll}28.5 & 33.6 & 29.8\end{array}$

$\begin{array}{lll}7.1 & u & 7.1^{*}\end{array}$

$13.0 \mathrm{u} \quad 13.1^{*}$

$25.5 \mathrm{u} 25.5^{*}$

$47.3 \mathrm{u} 47.3^{*}$

$12.3 \mathrm{u} \quad 12.3^{*}$

$21.3 \mathrm{u} 21.3^{*}$

$31.5 \quad 56.1$

37.7

*Includes only married women. Note: $u=u n a v a i l a b l e$.

method shifted from the pill to withdrawal. The trend toward more effective methods use among young females, mostly those in a union, suggests concerted efforts to prevent pregnancy by use of efficient methods; however, use of less efficient means, such as periodic abstinence, condoms and withdrawal continues to be common.

For the 34 countries for which we had data on both married and unmarried sexually active women from at least two surveys, we calculated each country's annual rate of change in contraceptive prevalence between the earliest and the most recent survey; the average interval between surveys was 11 years, with a range of 3-19 years. Ten countries had annual increases of more than 10\%, 14 increased $5-10 \%$ per year, and the remainder experienced smaller increases or remained constant, except for Chad and Rwanda, where contraceptive use decreased (see Web Appendix Figure 3 at http://www.guttmacher.org/pubs/

\begin{tabular}{|c|c|c|c|}
\hline $\begin{array}{l}\text { Country and } \\
\text { survey year }\end{array}$ & Married & $\begin{array}{l}\text { Unmarried/ } \\
\text { sexually active }\end{array}$ & $\begin{array}{l}\text { Married and } \\
\text { unmarried/ } \\
\text { sexually active }\end{array}$ \\
\hline Kazakhstan,1999 & 38.3 & 60.3 & 46.8 \\
\hline Kenya, 1989 & 13.0 & 12.0 & 12.8 \\
\hline Kenya, 2003 & 16.4 & 49.4 & 22.0 \\
\hline Madagascar, 1992 & 6.4 & 16.8 & 10.8 \\
\hline Madagascar,2004 & 12.7 & 30.8 & 17.5 \\
\hline Malawi, 1992 & 7.3 & $\mathrm{u}$ & $7.3^{*}$ \\
\hline Malawi,2004 & 18.9 & 25.3 & 19.6 \\
\hline Mali, 1987 & 8.6 & $\mathrm{u}$ & $8.6^{*}$ \\
\hline Mali, 2001 & 4.9 & 23.8 & 7.3 \\
\hline Morocco, 1987 & 17.0 & u & $17.0^{*}$ \\
\hline Morocco, 2003 & 38.4 & u & $38.4^{*}$ \\
\hline Mozambique, 1997 & 0.6 & 7.0 & 1.9 \\
\hline Mozambique, 2003 & 20.0 & 43.0 & 26.9 \\
\hline Namibia, 1992 & 20.5 & 29.0 & 26.5 \\
\hline Namibia, 2000 & 45.2 & 50.9 & 49.2 \\
\hline Nepal, 1996 & 6.5 & $\mathrm{u}$ & $6.5^{*}$ \\
\hline Nepal,2006 & 16.0 & u & $16.1^{*}$ \\
\hline Nicaragua, 1998 & 39.8 & 22.3 & 39.0 \\
\hline Nicaragua, 2001 & 55.2 & 53.4 & 55.1 \\
\hline Niger, 1992 & 2.2 & 20.6 & 2.4 \\
\hline Niger, 2006 & 4.3 & $\mathrm{u}$ & $4.3^{*}$ \\
\hline Nigeria, 1990 & 1.3 & 40.4 & 9.8 \\
\hline Nigeria, 2003 & 4.3 & 45.0 & 11.5 \\
\hline Peru, 1986 & 22.7 & $\mathrm{u}$ & $22.7^{*}$ \\
\hline Peru, 2004 & 56.7 & 85.5 & 65.3 \\
\hline Philippines, 1993 & 17.2 & u & $17.1^{*}$ \\
\hline Philippines, 2003 & 25.6 & u & $25.5^{*}$ \\
\hline Rwanda, 1992 & 10.8 & u & $14.7^{*}$ \\
\hline Rwanda,2005 & 3.2 & u & $3.6^{*}$ \\
\hline Senegal, 1986 & 9.5 & $\mathrm{u}$ & $9.5^{*}$ \\
\hline Senegal,2005 & 5.0 & u & $5.1^{*}$ \\
\hline Tanzania, 1992 & 5.2 & 10.4 & 6.9 \\
\hline Tanzania, 2004 & 9.6 & 31.8 & 14.4 \\
\hline Togo, 1988 & 16.7 & 51.4 & 29.0 \\
\hline Togo, 1998 & 15.0 & 56.2 & 34.2 \\
\hline Turkey, 1993 & 24.1 & u & $24.1^{*}$ \\
\hline Turkey, 2003 & 44.3 & u & $44.3^{*}$ \\
\hline Uganda, 1988 & 1.7 & 5.8 & 2.4 \\
\hline Uganda,2006 & 11.4 & 37.2 & 15.9 \\
\hline Vietnam, 1997 & 18.1 & $\mathrm{u}$ & $18.1^{*}$ \\
\hline Vietnam, 2002 & 22.8 & u & $22.8^{*}$ \\
\hline Zambia, 1992 & 8.7 & 5.5 & 7.7 \\
\hline Zambia,2002 & 25.5 & 22.6 & 24.9 \\
\hline Zimbabwe, 1988 & 30.0 & 34.8 & 31.0 \\
\hline Zimbabwe, 2005 & 36.7 & 36.8 & 36.7 \\
\hline
\end{tabular}

ipsrh/appendix/3506309.pdf). The increases were rapid compared with those during the 1970s and early 1980s, when contraceptive use rose more slowly. ${ }^{18}$

Given the striking trends in contraceptive use among adolescent females, we compared their annual rates of change with those of other age-groups. For each age-group included, contraceptive prevalence increased on average (i.e, the median country value was above zero-Figure 2, page 68). The median rate of change, however, was greatest for 15-19-year-olds, at about 5\% a year, followed by 20-24-year-olds, at about 3\% per year. In addition, the variation across countries was greatest for 15-19-year-olds. Although the prevalence of contraceptive use was gener-

*In spite of overall increases in prevalence among adolescents, the availability of more than two surveys for some countries shows that upward trends have stagnated or even reversed recently in some countries (e.g., Kenya, Tanzania and Uganda). 
FIGURE 2. Annual rate of change in contraceptive prevalence for all sexually active females of reproductive age, by age-group, in 45 countries, 1986-2006

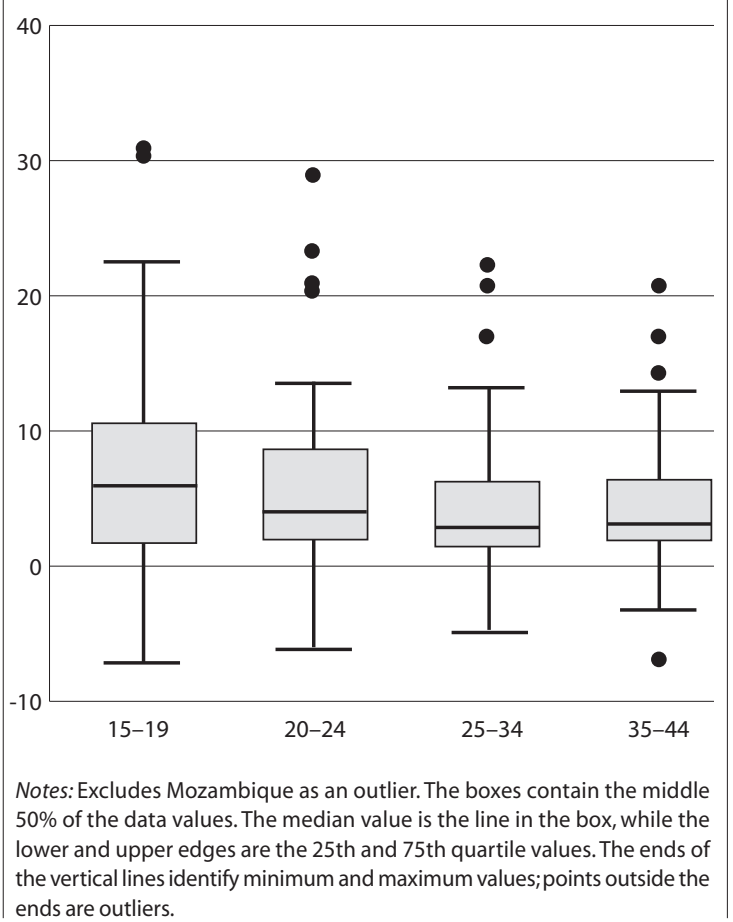

ally much lower among adolescents than among older women, the use of family planning methods expanded more rapidly over the last two decades among the youngest women.

\section{Discontinuation}

In almost every country, a greater proportion of 15-19-yearolds than of women aged 20-49 reported experiencing a contraceptive failure within a year of starting method use (Table 3). On average, failure rates for adolescents were about $25 \%$ higher than those for older women. This difference is likely due to several factors, including that adolescents tend to use less effective methods than older women (especially in countries where a substantial proportion of older women are sterilized), use methods less effectively and are more fecund. ${ }^{17,24}$ A few countries had notably high failure rates among young women, including Bolivia (19\%), where periodic abstinence is the most prominent method used by adolescents, and Jordan, the Philippines and Turkey (10-14\%), where withdrawal is the most common method.

The proportion of adolescent women who reported discontinuing their method while still in need of contraception ranged from 4\% in Morocco to $28 \%$ in Guatemala. In all countries except one, Ethiopia, a greater proportion of adolescents than of older women discontinued method use while still in need. Although the DHS data provide little insight into the reasons for this difference, it suggests that younger women face more obstacles to consistent use and perhaps that they are more likely to abandon a method and try another if they experience side effects. Because discontinuation while still in need puts women at risk of having an unwanted pregnancy, the rates would ideally decline over time, although there is little evidence that this has happened in most countries (not shown).

In all countries for which data were available, a greater proportion of adolescents than of their older counterparts

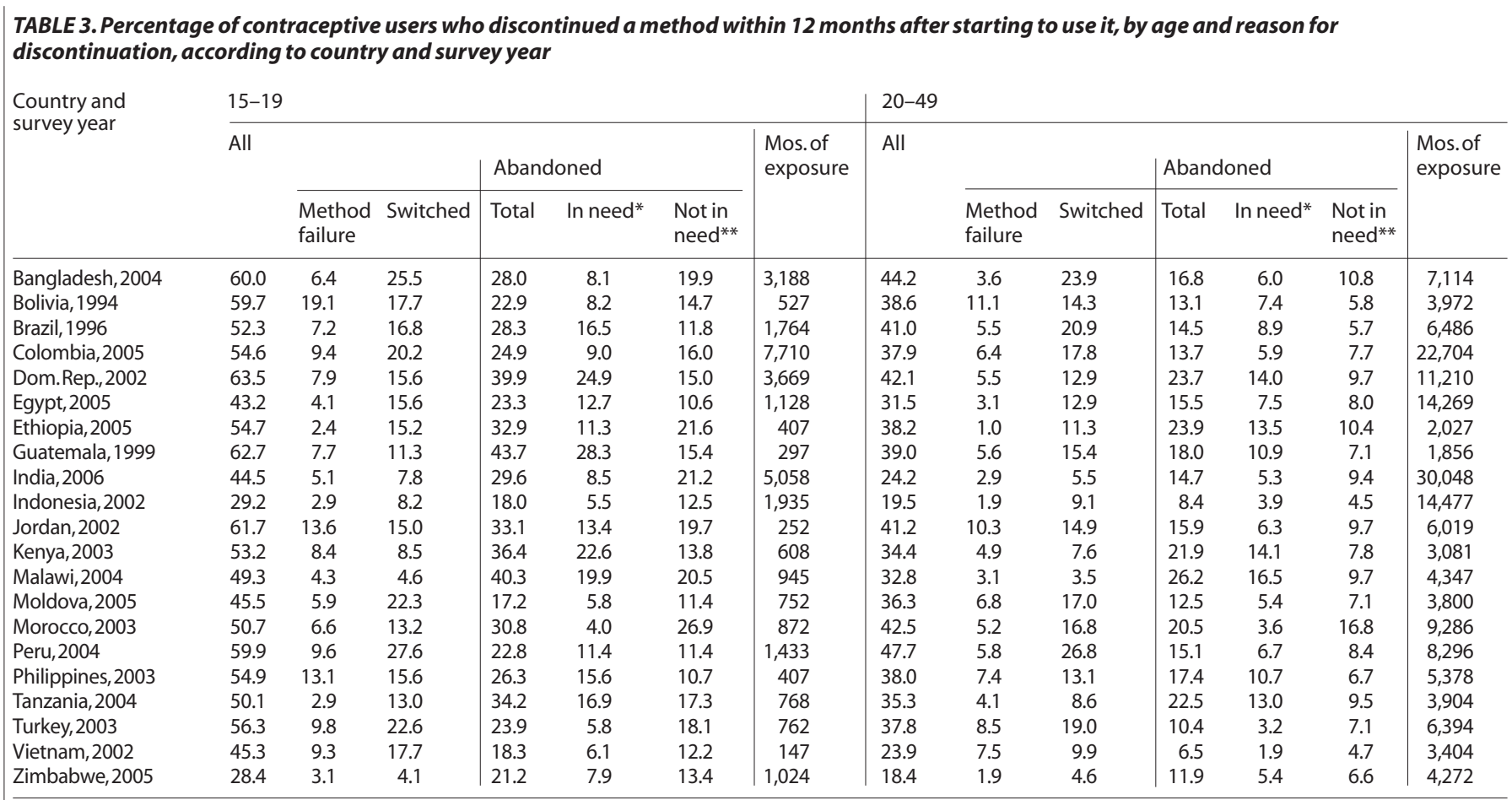

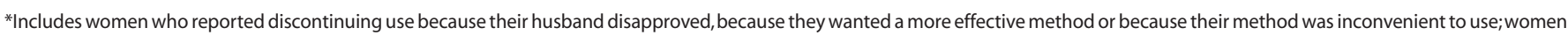
who discontinued because of side effects, health concerns, access or availability problems or other reasons; and those who responded "don't know." **Includes women who stopped using because they wanted to become pregnant or because of infrequent sex, menopause or infecundity, or marital dissolution. 
discontinued their method use within a year for any reason. Thus, compared with adult contraceptive use, adolescent use is characterized by shorter periods of consistent use, more contraceptive failure and more stopping for other reasons. This pattern is not surprising: Unmarried adolescents commonly report infrequent sex as a reason for not using contraceptives, ${ }^{19}$ and many married adolescents stop use to get pregnant.

\section{DISCUSSION}

In many of the countries included in this study, substantial proportions of 15-19-year-old women are married or are unmarried yet sexually active. The prevalence of marriage in this age-group has declined in the majority of countries included in this study. This decline has been accompanied in several countries by an increase in the prevalence of sexual activity outside of marriage, but there is a great deal of variation in the pattern of change, suggesting that country-level analyses of patterns of exposure to pregnancy risk by age are needed.

According to our findings, current use of contraceptives is often greater among unmarried sexually active women than among their married counterparts, especially in SubSaharan Africa. This suggests that young women at the onset of sexual activity are learning to use contraceptives to prevent unplanned pregnancies. At the same time, most adolescents in the study countries who are sexually active are married. Contraceptive use in this group has increased in most countries, and it has risen faster among adolescents than among older women. Contraceptive practice among adolescent women appears to involve much experimentation and inconsistent use. We find higher levels of method failure and method discontinuation while still in need among adolescents than among older females. This pattern has been seen in studies of U.S. adolescents, ${ }^{20,21}$ as well as in multivariate analyses of earlier DHS data. ${ }^{22-24}$ Further insights into the contraceptive dynamics of adolescents could be gained through a more detailed look at their adoption and discontinuation of specific methods and their reasons for discontinuing, as well as at the interaction between contraceptive use patterns and marital or relationship status.

Given the shift over time toward adolescents' lower desired family sizes and earlier initiation of contraceptive use, we can surmise that lifetime experience with and use of contraceptives through the reproductive years will grow. Because young people exhibit a clear pattern of contraceptive experimentation, it is likely that their lifetime practice will not be without failure, resulting in accidental pregnancies. An expanded demand for contraceptive supplies, services and information can be expected to challenge the preparedness, capacity and resources of existing family planning programs and providers. This trend of expanded demand is likely to be profound, both for the rising number of female contraceptive users and the public sector programs charged with providing family planning services.
There are many barriers to the use of family planning services by young people-including fear, embarrassment, cost and lack of knowledge. Thus, special efforts are needed to respond effectively to adolescents' needs. ${ }^{25}$ The quality of services offered to young people is likely to have an important effect on both their adoption and continuation of method use; their higher rates of contraceptive failure and method discontinuation while still at risk of an unwanted pregnancy suggest that existing service models are inadequate. For example, some family planning programs continue to restrict unmarried women's access to contraceptives; others emphasize methods that stop childbearing, such as sterilization, rather than those that delay childbearing.

The extent to which national public and private health care can respond to this growing need for effective, highquality pregnancy and contraceptive services in the coming decades will significantly influence the quality of reproductive health transitions among couples forming their families. Fortunately, the body of evidence on what makes for effective reproductive health programs for young people has grown over the last decade. Although there remains a shortage of rigorous evaluations of programs aimed at youth, there is now some evidence-based guidance that can be used to direct program and policy design. ${ }^{26,27}$ Community-based, life-skills programs and those aimed at couples have shown some promise for improving reproductive outcomes among young people, as have conditional cash transfer programs (e.g., those which give money for staying in school). ${ }^{2}$

The findings from this study indicate a need for resources to be invested in research that can illuminate the patterns and influences behind the sexual and reproductive health transitions experienced by cohorts of young people in developing countries. Personal, social and institutional factors determine the initiation, timing and shifting of contraceptive practices at a young age and have consequences for subsequent reproductive behaviors. Studying the changing dynamics of use, especially in relation to reproductive events, from the perspective of both genders requires investments in longitudinal data systems that have the potential to offer reliable explanations beyond what is possible from the macro-level overview offered in this study. Modeling individual-level change will help address issues regarding contraceptive adoption and continuation raised by this study and identify responsible contextual factors.

\section{REFERENCES}

1. Lloyd C, ed., Growing Up Global: The Changing Transitions to Adulthood in Developing Countries, Washington, DC: National Academies Press, 2005.

2.World Bank, Development and the Next Generation, World Development Report, Washington, DC: International Bank for Reconstruction and Development, 2007.

3. Levine R et al., Girls Count, Washington, DC: Center for Global Development, 2008.

4. Bongaarts J and Cohen B, Introduction and overview, Studies in Family Planning, 1998, 29(2):99-105. 
5. Cleland J, Ali M and Shah I, Trends in protective behavior among single versus married young women in Sub-Saharan Africa: the big picture, Reproductive Health Matters, 2006, 14(28):17-22

6. Pachauri S and Santhya K, Reproductive choices for Asian adolescents: a focus on contraceptive behavior, International Family Planning Perspectives, 2002, 28(4):186-195.

7. Godeau E et al., Contraceptive use by 15-year-old students at their last sexual intercourse: results from 24 countries, Archives of Pediatrics EAdolescent Medicine, 2008, 162(1):66-73.

8. Cleland J and Ali M, Sexual abstinence, contraception and condom use by young African women: a secondary analysis of survey data, Lancet, 2006, 368(18):1788-1793.

9. Ali M and Cleland J, Sexual and reproductive behavior among single women aged 15-24 in eight Latin American countries: a comparative analysis, Social Science \& Medicine, 2005, 60(6):1175-1185.

10. Blanc A and Way A, Sexual behavior and contraceptive knowledge and use among adolescents in developing countries, Studies in Family Planning, 1998, 29(2):106-116.

11. Mensch B, Grant M and Blanc A, The changing context of sexual initiation in Sub-Saharan Africa, Population and Development Review, 2006, 32(4):699-727.

12. Ali M and Cleland J, Reproductive consequences of contraceptive failure in 19 developing countries, Obstetrics \& Gynecology, 2004, 104(2):314-320.

13. MacPhail C et al., Contraceptive use and pregnancy among 15-24 year old South African women: a nationally representative cross-sectional survey, BioMed Central Medicine, 2007, Vol. 5, <http:// www.pubmedcentral.nih.gov/articlerender.fcgi?artid=2190760>, accessed June 11, 2009

14. Gomes K et al., Contraceptive method use by adolescents in a Brazilian state capital, Journal of Pediatric and Adolescent Gynecology, 2008, 1(4):213-219.

15. Sheeder J, Tocce K and Stevens-Simon C, Reasons for ineffective contraceptive use antedating adolescent pregnancies, part 1: an indicator of gaps in family planning services, Maternal and Child Health, 2009, 13(3):295-305.

16. Ross J and Winfrey W, Unmet need for contraception in the developing world and the former Soviet Union: an updated estimate, International Family Planning Perspectives, 2002, 28(3):138-143.

17. Blanc A, Curtis S and Croft T, Monitoring contraceptive continuation: links to fertility outcomes and quality of care, Studies in Family Planning, 2002, 33(20):127-140.

18. Special calculations of data from Ross J, Mauldin WP and Miller V, Family Planning and Population: A Compendium of International Statistics, New York: Population Council, 1993, Table 9.

19. Sedgh G et al., Women with an unmet need for contraception in developing countries and their reasons for not using a method, Occasional Report, New York: Guttmacher Institute, 2007, No. 37.

20. Woods J et al., Patterns of oral contraceptive pill-taking and condom use among adolescent contraceptive pill users, Journal of Adolescent Health, 2006, 39(3):381-387.

21. Glei DA, Measuring contraceptive use patterns among teenage and adult women, Family Planning Perspectives, 1999, 31(2):73-80.

22. Ali M and Cleland J, Determinants of contraceptive discontinuation in six developing countries, Journal of Biosocial Science, 1999, 31(3):343-360.

23. Leite IC and Gupta N, Assessing regional differences in contraceptive discontinuation, failure and switching in Brazil, Reproductive Health, 2007, Vol. 4, <http://www.pubmedcentral.nih.gov/ articlerender.fcgi? artid=1976606>, accessed June 11, 2009.

24. Curtis S and Blanc A, Determinants of contraceptive failure, switching, and discontinuation: an analysis of DHS contraceptive histories, DHS Analytical Reports, Calverton, MD, USA: Macro International Inc., 1997, No. 6.
25. Biddlecom A et al., Adolescents' views of and preferences for sexual and reproductive health services in Burkina Faso, Ghana, Malawi and Uganda, African Journal of Reproductive Health, 2007, 11(3):99-110

26. Family Health International (FHI), YouthNet End of Program Report. Taking Action: Recommendations and Resources, Arlington, VA, USA: FHI, 2006.

27. International Planned Parenthood Federation Western Hemisphere Region (IPPF/WHR), Effective Strategies in Sexual and Reproductive Health Programs for Young People, New York: IPPF/WHR, 2007.

\section{RESUMEN}

Contexto: Las decisiones que toman las mujeres y los hombres jóvenes en cuanto a su reproducción, tienen un enorme impacto en su salud, escolaridad, perspectivas de empleo y su transición a la vida adulta en general. Dado que la más grande cohorte de jóvenes en la historia está entrando en sus años reproductivos, su conducta reproductiva determinará el crecimiento y tamaño de la población mundial en las décadas por venir

Métodos: Se utilizó datos de Encuestas Demográficas y de Salud de más de 40 países, para examinar las proporciones de mujeres de 15-19 años de edad que estaban casadas; o que, no estando casadas, eran sexualmente activas; y sus tasas de adopción, uso y descontinuación de anticonceptivos, cambio de método y falla de anticonceptivos. También se examinó las tendencias en estos indicadores, y se realizó comparaciones con mujeres de mayor edad.

Resultados: En muchos países, la proporción de mujeres adolescentes que usan anticonceptivos aumentó sustancialmente en las últimas dos décadas; la prevalencia del uso anticonceptivo aumentó más rápido en las adolescentes que en mujeres de mayor edad. Una mayor proporción de adolescentes que de mujeres de mayor edad descontinuaron el uso anticonceptivo en un lapso de un año o tuvieron una falla de su método.

Conclusiones: El uso de anticonceptivos en adolescentes está creciendo y, comparado con su uso por personas adultas, está caracterizado por períodos más cortos de uso consistente, con más fallas de los anticonceptivos y con más interrupciones por otras razones. Es probable que crezca el uso de anticonceptivos a través de los años reproductivos, impulsado por el crecimiento en el número de jóvenes. Puede esperarse que una demanda expandida de suministros, servicios e información de anticoncepción ponga a prueba el grado de preparación, capacidad y recursos de los programas y prestadores de planificación familiar existentes.

\section{RÉSUMÉ}

Contexte: Les choix génésiques des jeunes femmes et hommes ont un impact énorme sur leur santé, leur scolarité, leurs perspectives d'emploi et leur transition globale vers l'âge adulte. Tandis que la plus vaste cohorte de jeunes de l'histoire accède à sa période de vie génésique, son comportement sexuel déterminera la croissance démographique et l'ampleur de la population mondiale à venir.

Méthodes: Les données d'Enquête démographique et de santé de plus de 40 pays ont servi à l'examen des proportions de 
femmes de 15 à 19 ans actuellement mariées ou célibataires mais sexuellement actives, de leurs taux d'adoption, de pratique actuelle, d'abandon, de changement de méthode et d'échec de la contraception, des tendances de ces indicateurs et à la comparaison par rapport à leurs aînées.

Résultats: Dans de nombreux pays, la proportion d'adolescentes qui pratiquent la contraception a augmenté considérablement au cours des 20 dernières années. Parmi les adolescentes, la prévalence s'est accrue plus rapidement que parmi les femmes plus âgées. De plus grandes proportions d'adolescentes que de femmes plus âgées ont cependant abandonné une méthode adoptée en l'espace d'un an ou ont connu un échec contraceptif.

Conclusions: La pratique contraceptive des adolescentes est en hausse et, par rapport à celle des adultes, elle se caractérise par de plus brèves périodes d'usage constant avec plus d'échecs contraceptifs et plus d'abandons pour d'autres raisons. La pratique contraceptive durant les années de fécondité devrait s'accroître, alimentée davantage encore par la croissance numérique des jeunes. La demande accrue de produits contraceptifs, de services et d'information mettra vraisemblablement au défi l'état de préparation, la capacité et les ressources des programmes et prestataires de planification familiale existants.

\section{Acknowledgments}

This study received partial support from the Bill and Melinda Gates Institute for Population and Reproductive Health, Johns Hopkins Bloomberg School of Public Health. The authors appreciate research assistance from Marissa Pine Yeakey.

Author contact: ablanc@engenderhealth.org 